\title{
digitalEDUCATION
}

\section{The end of Enlaces: 25 years of an ICT education policy in Chile}

\author{
Magdalena Claro \\ mclarot@uc.cl \\ Faculty of Education, Pontificia Universidad Católica de Chile \\ Ignacio Jara \\ ignacio.jara@udp.cl \\ Faculty of Education, Universidad Diego Portales
}

\begin{abstract}
This article analyzes the reasons behind the end of the ICT in education policy (Enlaces) driven by the Chilean Ministry of Education for 25 years. The argument is that the institution that sought to give sustainability to this policy over time, ended up losing its ability to lead relevant responses to the educational challenges posed by the growing digitalization of the Chilean society. To develop this argument, first we describe the main characteristics, history and results of Enlaces until 2018, and second, we analyze the institutional development of Enlaces in light of the challenges posed to ICT in education policies in the world.
\end{abstract}

\section{Keywords}

ICT education policy; Chile; digital literacy; digital society; educational institutional framework 


\section{Introduction}

This paper seeks to analyze the weaknesses and tensions underlying the end of Enlaces, the ICT in education policy (K-12) carried by the Chilean Ministry of Education for 25 years. The main argument is that this policy came to an end mainly because the Agency in charge of its implementation was unable to balance its own institutional framework with the dynamism and leadership required to respond to digital changes in society. This institutional impasse meant that although for over a decade the policy succeeded in giving timely access to and building basic capacities in the education system, it failed to adequately respond to the more profound challenges and transformations brought about by the growth and widespread use of these technologies in Chilean society. In other words, despite Enlaces' domestic and international legitimacy, in the process of its own institutionalization it failed to create, and engage the Ministry of Education in a comprehensive vision of the formative challenges faced by the school system on account of the digitalization of society, and lead the required changes in education policy.

The above situation occurred in a wider context where ICT in education policies have been rolled out from two different rationales: on the one hand a technocratic rationale in which digital technologies are adopted as a tool or "technical solution" (Selwyn, 2010) to render more effective the implementation of the prevailing education agenda and, on the other, a rationale that we will call "sociocultural", which regards digital technologies as having a role in transforming the wider society and therefore calls for reviewing and making changes in the prevailing education policy, especially in terms of its curriculum and capacity-building among education actors (Erstad \& Voogt, 2018; Williamson, 2013). Our thesis is that this tension is inherent to ICT in education policies, which are called to respond to the social challenges posed by the growing digitalization of society vis-á-vis education systems that lean toward bureaucratization and are resistant to change (Williamson, 2013). The ICT education policy in Chile is a case which failed to adequately manage this tension in the long term and which, during the institutionalization of the responsible agency, gradually lost its capacity for self-renewal, and eventually leadership and relevance for the country's education system.

This article first describes the main characteristics of Enlaces, its history, institutional framework and results until 2018. It then makes a critical analysis of the institutional framework developed in Chile based on the role that a digital education policy should play in addressing the social changes of the 21st century.

\section{The ICT education policy in Chile and its institutionalization process}

\section{a. Creation and institutional history of Enlaces}

This section briefly reviews the main milestones associated to the institutional history of Enlaces (see summary in Table 1 ).

The ICT in education policy in Chile was enacted in 1992 with the creation of Enlaces, a pilot project aimed at testing a model for the educational use of technology in primary schools led by a university in the south of the country (Universidad de la Frontera). In 1995 the model began to expand to primary and secondary schools in the rest of the country with the aim of providing access to and foster the use of digital technologies to enhance students' learning in school subjects and develop their digital skills. The model included technological infrastructure, digital educational resources, and countrywide teacher training and support (Hepp, 2003). 
Nationwide teacher training and support to schools were provided through the creation in 1996 of the Enlaces National Support Network (RATE), which involved partnering with more than 20 universities across the country (Jara, 2003). The mission of this network was to train teachers and provide them with technical and pedagogical support. To accomplish this task, primary and secondary teachers specializing in educational technology were hired by the universities as trainers who kept in permanent touch with the schools to support the use of digital technologies.

To support coordination of the nationwide expansion of Enlaces and the National Support Network, the Ministry of Education created an internal unit that worked with the Universidad de la Frontera. This hybrid (Universidad-Ministry) organization operated until the early 2000s, when full responsibility was transferred to the Ministry team, although the universities continued to be involved in the policy, providing support to schools and a more flexible vision geared to continuous inquiry and innovation. While the Ministry-based team worked in coordination with other ministerial programs and implemented international tenders to purchase and distribute equipment and monitor the performance of provider companies-all of which was carried out through the State bureaucracy-the universities worked directly with the schools and acted as a buffer zone, always keeping in touch with ideas and research from the academia.

In 2005 the Ministry of Education formalized its internal administrative unit as the Center for Education and Technology (CET) to host Enlaces and provide status and stability to the ICT in education policy. This new Center was placed within the Ministry of Education and reported directly to the Undersecretary of Education so as to facilitate linking Enlaces with the rest of the education policies and ministerial administrative units. This position of relevance became gradually blurred over time: starting in 2010 the CET began to be coordinated by the Information Technology Department of the Ministry, while in 2015 it was formally placed under the jurisdiction of the Ministry's General Education Division, i.e. the unit responsible for providing educational support to schools.

Despite these changes, the CET was responsible for the design and implementation of the ICT education policies until its closing in 2018. This unit grew to over 50 people, including professionals and administrative staff distributed into four main areas: ICT Training and ICT Competencies, Digital Educational Resources, Technological Infrastructure, and ICTs for Management and Learning. Each of these areas implemented different policy initiatives with the help of different entities outside the Ministry of Education such as technological firms, universities, foundations and NGOs (Jara, 2013).

In 2018, the CET and the Enlaces program it hosted were subsumed under the Center for Innovation in Education, created by the administration that came to power that year for promoting educational innovation within the school system. Just like the original CET, the new center was to report directly to the top officials within the Ministry. What this meant in practice was that both the professional teams and the budget of the CET-Enlaces became part of the newly-formed center. Although the closing of the CET-Enlaces did not mean the cancellation of all their initiatives, nor the abandonment by the Ministry of Education of all issues in connection with the use of digital technologies in schools, it did imply the end of the policy that for over 25 years had been responsible for proposing and implementing a vision and an agenda on the adoption of such technologies in school education. These issues have since then been promoted from the larger framework of educational innovation adopted by the new Center for Innovation.

The only initiatives that were left from the CET-Enlaces' agenda were those in support of school infrastructure, in particular, those related to improving school connectivity, which have been strengthened based on a project called Connected Classrooms (Aulas Conectadas). The new Center 
also launched a technology-related initiative called National Plan for Digital Languages (PNLD), which seeks to promote the learning of computer thinking and programming in the school system.

\begin{tabular}{|l|l|}
\hline Year & \multicolumn{1}{c|}{ Institutional Milestone } \\
\hline 1992 & Creation of pilot project Enlaces. \\
\hline 1996 & $\begin{array}{l}\text { Creation of the National Support Network (RATE). } \\
\text { Coordination of Enlaces undertaken by University of The Frontera, with support } \\
\text { provided by the Ministry of Education's internal administrative unit. }\end{array}$ \\
\hline 2001 & $\begin{array}{l}\text { Coordination of Enlaces undertaken by the Ministry of Education's internal } \\
\text { administrative unit, with support provided by University of The Frontera. }\end{array}$ \\
\hline 2005 & Creation of the Center for Education and Technology (CET). \\
\hline 2018 & Closing of Enlaces and creation of the Center for Innovation in Education (CIE). \\
\hline
\end{tabular}

Table 1. The institutional history of Enlaces, the ICT in education policy in Chile

Source: Author

\section{b. Vision and main strategies promoted by Enlaces}

As mentioned earlier, the Enlaces policy was created and developed based on the idea of providing access to and promoting the use of digital technologies for improving students' learning of school disciplines as well as developing their skills to leverage digital opportunities.

\section{Access}

In terms of access, Enlaces provided computers mainly through the implementation of computer laboratories in schools and mobile computer laboratories. Like many countries in the region such as Colombia, Mexico, Costa Rica and Brazil, and unlike Uruguay-which implemented access through One Laptop per Child policies-the Chilean policy basically opted for handing ownership of computers to the institutions so that the entire school community could make use of them during class and out of school time. Thus, in the early 2000s laboratories were also used as community telecenters for providing training and access to families in the school neighborhood. These strategies have allowed the number of computers available per student in Chilean schools to be similar on average to that of OECD countries (OCDE, 2015). Notwithstanding the above, in the last decade strategies to give personal computers to students in some grade-levels were implemented by means of two initiatives. One of them called Yo elijo mi PC (I choose my PC) was intended to benefit vulnerable seventh-grade boys and girls excelling in school performance and started in 2008. The second one, called Me Conecto para Aprender (I Go Online to Learn), which began in 2015, has provided one laptop to every seventhgrade municipal-school student who has not received one through another program. The equipment provided includes free, guaranteed, 12-month mobile wide-band service, educational software, laptop rucksack, among others (MINEDUC, 2016). In terms of school connections, since 1998 Enlaces installed Internet in Chilean schools with the support of private enterprises, reaching mass coverage in the early 2000s except for rural schools due to challenging conditions such as geographical distance and the difficulties of mountainous territory (Donoso, 2010). 


\section{School uses for improving students' learning of school disciplines}

One of the initial strategies promoted by Enlaces through the establishment of the National Support Network was to train Chilean teachers in the use of digital technologies in support of school subjects. It also offered technical and pedagogical support by instituting the role of an Enlaces coordinator within the school. On the other hand, it sought to support teachers by defining a set of competencies and standards to identify and define the types of ICT usage expected from teachers in the various areas of their profession. Competencies were defined in five domains: pedagogical, technical, administrative, ethical and legal, and career development (Enlaces, 2010; Bilbao \& Salinas, 2013). Enlaces has delivered education programs directly to schools in support of the curriculum and, alongside with Fundación Chile, implemented the Educar Chile portal (www.educarchile.cl), whose purpose has been to offer educational resources to teachers, school leaders and the school community at large. Finally, a student-oriented digital resources platform called Yo Estudio (I Study) was concurrently implemented, featuring domestic and international educational resources such as software, simulators, animations and videos to reinforce and supplement contents for students in grades first through twelfth (Mineduc, 2013).

\section{Developing students' digital skills}

Enlaces gradually promoted the introduction in the curriculum framework of some descriptions of what students are expected to achieve in terms of their digital skills. Starting in 1998 in secondary education and in 2008 in primary education, these skills were officially introduced as a set of crosscurricular objectives with an emphasis on computer literacy and on supporting the learning of school disciplines. Later on in 2012, Enlaces defined what it called ICT Skills for Learning Matrix, which adopted a wider concept of digital skills that included information and communication skills in digital environments, integrating them into the objectives of some school subjects across the curriculum (Mineduc, 2012). At the same time, it implemented a nationwide digital skills assessment called SIMCE TIC, which was administered to tenth-grade students in 2011 and 2013. Although this assessment provided valuable information, it was no longer administered after 2013. From that year on, however, Chile has participated in the two administrations of the International Computer and Information Literacy Study (ICILS) sponsored by the International Association for the Evaluation of Educational Achievement (IEA) (Fraillon et al., 2014; 2019).

\section{Results}

As regards access, Enlaces succeeded in giving access to computers and Internet to a vast majority of school enrollment in the 1990s and 2000s, at a time when they were available only to a minority of students and their families in their homes. For example, by 2002 residential connections reached a mere 10 percent (Subtel, 2002) while about 60 percent of the schools had Internet access (Enlaces, 2010). As years went by, however, Enlaces' contribution to reducing the Internet access gap has gradually lost relevance due to students' growing access to Internet both at home and through mobile phones. In fact, most school-age children and adolescents nowadays have Internet access through a Smartphone or a fixed home connection (Cabello \& Claro, 2017). On the other hand, some of the Enlaces challenges are still to be met in the area of school connectivity. In fact, 20 percent of the schools (most of which are rural and cover slightly less than 10 percent of school enrollment) still lack Internet access and the quality of connectivity in large urban areas is not sufficient to conduct online learning activities and download educational resources in a continuous, seamless manner (SITEAL, 2015). 
In terms of Enlaces' contribution to students' learning, as in the case of other countries, the results yield no conclusive evidence. On the one hand, these types of usage differ in frequency and quality and their impact on large-scale learning of school subjects has yet to be ascertained (Raczynsky, 2000; Contreras et al., 2008; Peirano \& Kluttig, 2009). Positive effects have been found only in smallscale studies about the use of resources in very specific subject areas and contexts (Sanchez \& Salinas, 2011; Jaramillo \& Chavez, 2015). On the other hand, however, research shows that there are myriad experiences in the use of digital technologies in the different disciplines, and that there are examples where such use enhances learning by giving access to high-quality learning resources and linking the classroom with realities and knowledge which cannot be accessed otherwise (Dockendorff \& Solar, 2017).

In connection with teaching skills and practices, the expectation has been that, thanks to the opportunities for interaction, representation, communication and simulation, the use of digital technologies would motivate teachers to change traditional teaching practices towards more innovative and interactive ones that allow students to be more actively involved in their own learning. In this regard, the Chilean evidence is consistent with international studies that indicate that although digital technologies are being increasingly used in teaching practices, such use often fails to go beyond supporting traditional teaching (Brun \& Hinostroza, 2011; Hinostroza, Labbe, Brun \& Matamala, 2011) and/or asking students to seek information in Internet for completing school assignments at the laboratories (Agencia de Calidad de la Educación, 2017; Arancibia, Cosimo \& Casanova, 2018). Moreover, evidence shows that teachers generally fail to guide the cognitive process of investigating and doing assignments using Internet in the context of their subject areas (Claro, Salinas, Cabello, Preiss, et.al., 2018). Part of the difficulties they report relate to the working conditions for introducing and leading the use of digital technologies in their lessons. Indeed, according to the International Computer and Information Literacy Study (ICILS), 57 percent of the teachers state they have insufficient time for preparing lessons involving the use of ICTs, while 40 percent report that their school has limited connectivity (ICILS information cited in Agencia de Calidad de la Educación, 2017).

As to developing digital skills, as noted earlier Chile has assessed students' ability for solving information and communication problems in digital environments through the ICILS international study administered to eighth-grade students in 2013 and 2018, and through the nationwide SIMCE TIC assessment administered to tenth-grade students in 2011 and 2013. Both studies are consistent in showing that Chilean students rank at middle to low levels in these skills. More specifically, in ICILS Chilean students scored on average 476 points, i.e., below the international mid-point (496 points), and above the score obtained by only two of the 14 participating countries, Uruguay (450 points) and Kazakhstan (395 points). In terms of achievement levels, in Chile 20 percent of the students scored lowest (with the countries' mean at 18 percent), while less than one percent of them succeeded in demonstrating the skills associated to the highest level (Fraillon et al., 2019). The above results are generally consistent with the results of the last administration of the nationwide SIMCE TIC assessment in 2013, according to which 46.9 percent of the students scored at the basic skills level, 51 percent scored at the intermediate level and only 1.8 percent at the advanced level (Centro de Educación y Tecnología - ENLACES, 2014). On the other hand, an analysis of the factors accounting for differences in the results of this assessment shows that home computer access, the linguistic capital, the socio economic level, and the number of years of computer use are still highly relevant in Chile (Autor et al., 2012; Autor et al., 2015). The results of these assessments reveal that a large number of Chilean students lack the skills to adequately learn in digital environments and that, as with other areas of performance, there are gaps among students from different socioeconomic and cultural level. These results are reinforced by the ICILS 2018 data, where Chile and Uruguay stand out as the two 
countries with the largest differences in the results between students whose parents fall into the higher education group (Bachelor's degree or higher) and lower education group (short-cycle tertiary or below) (Fraillon et al., 2019). The foregoing points to the fact that rather than shrinking, inequalities end up replicating themselves in digital environments with the use of technologies at school, which in turn shows how important it is for the education system to play a more effective role in the development of students' digital skills .

\section{The end of the ICT education policy in Chile}

This section analyzes the reasons for closing the CET-Enlaces in the light of its institutional history, strategies and main results as presented in the two preceding sections. Although the closing of the CET-Enlaces in 2018 did not mean the cancellation of all their initiatives, nor the abandonment by the Ministry of Education of the issues in connection with the use of digital technologies in schools, it did imply the end of the policy that for over 25 years had been responsible for proposing and implementing a vision and an agenda on the adoption of such technologies in school education. From then on these issues were placed in the wider context of educational innovation proposed by the Ministry of Education's newly-created Center for Innovation, with digital technologies being henceforth defined as support tools for school innovation and the ensuing blurring of the Enlaces policy objectives of preparing students for an increasingly digital society. Among the many possible causes of this discontinuance, some may be more structural while others may be more circumstantial. We propose here that the most important cause was the problematic institutional framework which was created based on the CET to maintain the continuity of the Enlaces policy. Our statement is that one of the main roots of what led to the closing of the CET-Enlaces may be found in its failure to combine its institutionalization process with the dynamism and leadership required to put forward appropriate answers to the formative challenges associated with the growing digitalization of society. These institutional hurdles hindered Enlaces from fostering an education policy in keeping with the new contexts, whereby it became increasingly more irrelevant and weaker in the face of attempts by any new authority that needed its resources to raise other initiatives, as it eventually happened in 2018.

ICT education policies worldwide all have in common the objective of preparing students to participate in the digital society (Eickelmann, 2018). To accomplish this objective, such policies should be able to manage a proper balance between sustaining achievements and remaining flexible enough to lead an education policy responsive to the social and technological changes in the country. As noted in the preceding section, after its establishment and expansion-which was heavily based on the country's university system (initially the University of The Frontera and then RATE)-and as part of its growth and maturity, in the early 2000s the policy underwent an institutionalization process deemed necessary for its consolidation and linkage with the rest of the public education institutional framework. This process was intended to formalize and consolidate the organizational and financial capabilities to enable the policy to deepen its agenda and articulate it with the other educational agencies or divisions responsible for the most critical public education tasks (curriculum, teacher training, financing, regulation, among others) (Hepp, 2003; Jara, 2003b). This process culminated in 2005 with the creation of the CET, which was placed within the Ministry of Education. This allowed the center to be closer to the education policy and budget resources, but made it more vulnerable to the ups and downs of changes of government; more firmly embedded in the State bureaucracy and further away from the capacities for innovation and linkage with the country's schools which were previously provided by the RATE (Severin, 2017). 
We state that the institutional design established in 2005, whereby the CET was placed within the Ministry of Education rather than outside it-as is the case with similar policies round the world (Trucano, 2017)-had flaws which weakened its leadership and autonomy to foster an ICT education policy with its own objectives and with the ability to respond to the digital challenges of society. Three were the fundamental problems in connection to the CET's institutional framework. First, although that was the idea upon the Center's inception, it never succeeded in becoming formalized into the organizational structure of the Ministry of Education. This allowed successive administrations to relocate it within the ministerial organizational design according to the idiosyncrasies of their agendas and the incumbent authorities. In 2010, for example, the CET was placed under the aegis of the Ministry of Education's Information Technology Department and in 2015 it was subsumed under the General Education Division (MINEDUC, 2017). In this manner, the CET's influence and linkage with the rest of the ministerial units was left exposed to the priorities of the authorities then in office, who generally view technology as a component marginal to the education policy (rather linked to equipment distribution and "good photos") or as a mere support for other policies deemed to be the truly relevant ones.

A second problem was that ever since is institutionalization the agenda gradually expanded and lost focus. In the early 2000s the focus of Enlaces was on expanding a proposal for integrating digital technologies for schools throughout the country (computer laboratories with digital educational resources and teacher training). Ten years later, Enlaces' offering had greatly diversified, but the scope and duration of each initiative had become increasingly limited (Donoso, 2010). And a third problem was that since its institutionalization within the Ministry, Enlaces became increasingly separated from the RATE (universities network) until the latter was finally left out. As a consequence, Enlaces lost direct linkage to the country's universities and schools, and became increasingly dependent on other programs for implementing its strategies.

The above description of the Enlaces case raises questions about the institutional design of this type of policies. According to Trucano (2017), there are no rules about the best institutional place for this type of agencies, while a proper balance can be reached between the capacities required for managing the digital agenda and the necessary autonomy to create the policy and drive its own objectives. The inability of Enlaces' institutional design to sustain and project the Chilean digital policy raises doubts about the likelihood of units internal to the ministries being a viable alternative. On the contrary, many of the countries with more successful and long-lasting ICT policies have opted for placing their agencies outside their Ministries of Education-such as the case of CEIBAL in Uruguay, KERIS in Korea, FOD in Costa Rica and BECTA in the UK, among others-although this design may not be sufficient either to guarantee institutional stability and permanence over time, as evidenced from the case of BECTA, which was closed down in 2011 (Trucano, 2017).

In brief, we propose that a failed institutionalization process left Enlaces in a marginal position within the Ministry of Education, and that this in turn undermined its ability to define, renew and develop a technologies-in-education policy relevant to the country, causing it to lose its linkages to society and the territories through partnering with the universities. As a result, the CET often ended up having the role of providing a "technical solution" for implementing other education policies which were a priority within the Ministry-such as the educational innovation policy put in place in 2018 in its own premises and which in practice led to the closing of the center. In other words, the CET's institutional arrangement led to Enlaces' losing its ability to adapt to social changes and to impact the education policy and the instruments through which the school system is guided and governed. 


\section{The role of ICT education policies in the 21 st century}

What ICT education policies worldwide all have in common is that they focus on preparing the new generations for an increasingly digital society. This role, however, has often been under stress as they have also been viewed as a technical solution to the problems of effectiveness of the prevailing educational policies. By failing to produce such solutions, they have been subject to strong criticism and have lost legitimacy. Nevertheless, as noted by Voogt, Knezek, Christensen \& Lai (2018), although in the early 2000s the focus was on the use of digital technologies in the curriculum for reinforcing learning of school subjects as well as for inter-disciplinary topics, the last decade has seen a renewed discourse about the need for a major review of what should be taught in the 21st century in view of the digital changes in society. In this regard, several states and countries in the world are redesigning their curricular frameworks (Voogt et al., 2018)

Consistent with the above, this article suggests that the challenges posed by the digitalization of society require ICT education policies with the ability to bring in a vision and solutions for dealing with the various dimensions that these changes involve. The Internet and digital technologies raise questions about the principles upon which school systems have been organized and the capacities of those responsible for the educational process. More specifically, the Internet provides unlimited access to information, learning resources and social media that call into question teacher's traditional frontal role and modify subject-based practices and knowledge (Dussel \& Quevedo, 2010; Hague \& Payton, 2010). In language, for example, reading has been transformed by digital multimodality, as new text formats, reading objectives and modes of interacting with information have been created (Liu \& Ko, 2019; Merchant, 2013). In history, working with sources is being challenged by new digital storage possibilities and the large amount of information and sources that can be accessed through the Internet (Hangen, 2015). In science and mathematics, information searches, data analysis and simulation or artificial intelligence-based technologies provide new opportunities for representation, visualization and knowledge creation (Dockendorff \& Solar, 2017; Perera \& Aboal, 2018). In visual arts, as well as in science and mathematics, 3D simulation and digital fabrication technologies provide for the creation of objects and new situated problem solving opportunities (Halverson \& Sheridan, 2014). With regards to social skills, students' increasing use of social media in and outside the classroom requires to define new protocols and foster socio-emotional skills for them to participate in a safe and responsible way in the digital sphere (Kane, Ng-A-Fook, Radford, \& Butler, 2017). Finally, the increasingly network-based social organization is slowly blurring the school boundaries, challenging the distinctions between formal and informal learning (Erstad, 2012) and the notion of the school organization as a closed entity (Williamson, 2013).

The above-mentioned challenges are new to the school system and a large part of the school leaders and teachers in Chile have not been prepared to address them. One of the essential tasks of a digital education policy at present is to offer guidelines and ensure the conditions for educational communities to be able to address these challenges. This has at least two implications. First, it means reviewing curriculum contents and skills in the light of digital changes, as some countries have already been doing (Voogt et al., 2018). To this end, it is not sufficient to marginally introduce a few digital tools and skills into the curriculum as has been done in Chile to date. Social media, cell phones and other contemporary technologies are not just tools, but new forms of mediation and representation of the world and in this sense new cultural forms (Buckingham, 2015). Thus, digital literacy needs to be included in the curriculum so as to enable students not only to learn how to use these technologies but also to critically understand how they work and their implications in their own lives (Buckingam, 2015; 
Pangrazio, 2016). This brings up the necessity to make more in-depth revisions of the contents and the fixed structure that currently characterize the Chilean school curriculum.

The second implication is the need to acknowledge that digital changes are defying socializing agents such as the home and school to redefine or re-contextualize their role. The concept of socialization refers to the way in which individuals become members of a society (Berns, 2012). In the case of schools as socializing agents, the Internet challenges the way in which teaching is organized and the role played by the teacher in that process. This means to understand the teachers' role in connection with students' new characteristics and experiences linked to the digital sphere and, based on this understanding, to reformulate the source of their authority, their subject-based objectives and their teaching methodologies (Dussel \& Quevedo, 2010; Claro et.al., 2018). School leaders and teachers should be trained in these new abilities and communities need to be supported to define and advance educational projects that address these changes considering their own sociocultural contexts. Although the Center for Training, Experimentation and Pedagogical Research (Centro de Perfeccionamiento, Experimentación e Investigación Pedagógica)-the Ministry's unit in charge of building teaching capacities-has started to target support for local capacity building, both the central Ministry's guidelines and a high-stakes evaluation system severely restrict the schools' autonomy and opportunities for innovation. It is of relevance, therefore, to promote mechanisms in support of new educational responses, considering performance indicators consistent with the development of skills that foster this type of experiences instead of more traditional learning outcomes indicators.

In summary, the increasing relevance of digital technologies in people's lives and society as a whole requires digital policies that call for major reforms of education systems-that go beyond promoting access and the use of digital technologies and resources in the teaching-learning process as Enlaces did in the 1990s and 2000s. Enlaces managed to deal with the access and literacy challenges required at the time with relative effectiveness; however, its institutional design since the inception of the CET failed to create the conditions for it to lead an education reform to adequately respond to the digitalization of society.

\section{Conclusions}

Enlaces, the technology in education policy in place in Chile for over 25 years, was discontinued in 2018 under a new administration that refocused its resources toward an agenda centered on educational innovation. At the heart of this measure is Enlaces' weak institutional design, which failed to empower it to manage the balance-inherent in this type of efforts-between using technology to deal with educational problems and leading an education agenda responsive to a new context transformed by digital technologies; between sustaining achievements and responding to changes, and between managing an initiatives agenda to support schools education projects and shaping a new vision for the future.

The ICT education policy in Chile is a case which-despite its countless contributions to schools' digitalization and connectivity, provision of digital resources and extensive training-failed to adequately resolve the technologies policy tension between a technocratic rationale in which digital technologies are adopted as a technical solution to implement the education agenda, and a sociocultural rationale which calls for acknowledging the transforming power of digital technologies in 
society and revising the prevailing formative model. Enlaces' institutional framework within the Ministry of Education entailed a better articulation with the education policy, but gradually restricted its capacity to renew the vision and the agenda, as well as to impact on the rest of the education policy. Although there is no easy ready-made solution, this experience raises questions about the institutional designs for this type of policies and suggests that the transformation of the education system, as is required by technological changes in society, demands organizational arrangements not easily sustainable within ministerial structures. It also suggests the need to consider external or mixed institutional frameworks capable of working directly with the school system structure while at the same time carrying out an education policy that strengthens local capacities to appropriately prepare the new generations to become critical workers and citizens of an increasingly digital society.

\section{References}

Agencia de la Calidad de Educación (2017). Percepciones acerca del uso de Tecnologías de Información y Comunicación (TIC) y los aprendizajes de los alumnos de enseñanza media. Santiago, Chile.

Arancibia, M., Cosimo, D., \& Casanova, R. (2018). Percepción de los profesores sobre integración de TIC en las prácticas de enseñanza en relación a los marcos normativos para la profesión docente en Chile, doi: org/10.1590/s0104-40362017002501119. Revista Ensaio: Avaliaçao e Políticas Públicas em Educaçao, 26(98), 163-184.

Bilbao, A. \& Salinas, A. (eds.) El Libro Abierto de la Informática Educativa: Lecciones y Desafíos de la Red Enlaces. Mineduc: 2013.

Brun, M., \& Hinostroza, J. E. (2011). Research on ICT integration for enhancing quality in teacher education: Nationwide policy or global challenge. Developing quality cultures in teacher education: Expanding horizons in relation to quality assurance, 99-118.

Buckingham, D. (2006). Defining digital literacy: What do young people need to know about digital media? Digital Kompetanse-Nordic Journal of Digital Literacy, 1 (4), 263-276. Henta frå idunn.

Cabello, P. \& Claro, M. (2017). General Results, Kids Online Survey Chile. Santiago: Kids Online Chile.

Claro, M., Salinas, A., Cabello-Hutt, T., San Martín, E., Preiss, D. D., Valenzuela, S., \& Jara, I. (2018). Teaching in a Digital Environment (TIDE): Defining and measuring teachers' capacity to develop students' digital information and communication skills. Computers \& Education, 121, 162-174.

Choi, M. (2016). A concept analysis of digital citizenship for democratic citizenship education in the internet age. Theory \& research in social education, 44(4), 565-607.

Dockendorff, M., \& Solar, H. (2018). ICT integration in mathematics initial teacher training and its impact on visualization: the case of GeoGebra. International Journal of Mathematical Education in Science and Technology, 49(1), 66-84.

Donoso, G. (2010), Enlaces en el sistema escolar chileno: evolución de sus cifras, en: El Libro Abierto de la Informática Educativa: Lecciones y Desafíos de la Red Enlaces, Santiago de Chile: Ministerio de Educación.

Dussell, I. \& Quevedo, LA (2010). Educación y nuevas tecnologías: los desafíos pedagógicos ante el mundo digital. Fundación Santillana.

Eickelmann, B. (2018). Cross-National Policies on Information and Communication Technology in Primary and Secondary Schools: An International Perspective. Second Handbook of Information Technology in Primary and Secondary Education, 1-12.

Erstad, O. (2012). The learning lives of digital youth-beyond the formal and informal. Oxford Review of Education, 38:1, 25-43, DOI: 10.1080/03054985.2011.577940

Erstad, O., \& Voogt, J. (2018). The twenty-first century curriculum: issues and challenges. Second Handbook of Information Technology in Primary and Secondary Education, 1-18.

Facer, K. (2011). Learning futures: Education, technology and social change. Londres: Routledge. 
Fraillon, J., Ainley, J., Schulz, W., Friedman, T. and Gebhardt, E. (2014). Preparing for Life in a Digital Age: The IEA International Computer and Information Literacy Study, International Report, IEA: Springer Open.

Fraillon, J., Ainley, J., Schulz, W., Friedman, T. and Duckworth, D. (2019). Preparing for Life in a Digital Age: IEA International Computer and Information Literacy Study 2018 International Report, IEA. Available in www.iea.nl.

Hague, C., \& Payton, S. (2010). Digital literacy across the curriculum. Austria: Futurelab.

Halverson, E. R., \& Sheridan, K. (2014). The maker movement in education. Harvard educational review, 84(4), 495-504.

Hangen, T. (2015). Historical Digital Literacy, One Classroom at a Time. Journal of American History, 101(4), 11921203. https://doi.org/10.1093/jahist/jav062

Hepp, P. (2003). Enlaces: el programa de informática educativa de la reforma educacional chilena, en: Políticas educacionales en el cambio de siglo: La reforma del sistema escolar de Chile, C. Cox, Santiago, Chile: Editorial Universitaria.

Hinostroza, J. E., Labbé, C., Brun, M., \& Matamala, C. (2011). Teaching and learning activities in Chilean classrooms: Is ICT making a difference?. Computers \& Education, 57(1), 1358-1367.

Jara, I. (2003), La experiencia chilena de la Red Enlaces, en: Educación y Nuevas Tecnologías: Experiencias en América Latina, Buenos Aires: Unesco.

Jara, I. (2003b). La organización central de los programas de mejoramiento de la calidad de la educación escolar chilena en los noventa, en: Políticas educacionales en el cambio de siglo: La reforma del sistema escolar de Chile, C. Cox, Santiago, Chile: Editorial Universitaria.

Jara, I. (2013). Las políticas TIC en los sistemas educativos de América Latina: Caso Chile. Unicef: Buenos Aires.

Jaramillo \& Chávez (2015). TIC y educación en Chile: Una revisión sistemática de la literatura. Nuevas Ideas en Informática Educativa TISE. Kane, R. G., Ng-A-Fook, N., Radford, L., \& Butler, J. K. (2017). Conceptualizing and contextualizing digital citizenship in urban schools: Civic engagement, teacher education, and the placelessness of digital technologies. Citizenship Education Research Journal, 6(1), 2438.

Liu, I. F., \& Ko, H. W. (2019). Roles of paper-based reading ability and ICT-related skills in online reading performance. Reading and Writing, 32(4), 1037-1059.

Merchant, G. (2013). The Trashmaster: literacy and new media, Language and Education, 27:2, 144-160, DOI: $10.1080 / 09500782.2012 .760586$

Peirano, C., Kluttig, M., Vergara, C. (2009), Evidencia sobre el uso de tecnologías y su correlación con el desempeño en Pisa-Ciencias 2006 en ¿Qué nos dice PISA sobre la educación de los jóvenes en Chile?, Ministerio de Educación de Chile, Santiago de Chile: Ministerio de Educación.

Raczynski, D. and Pavéz, A. (2000), Diseño de un modelo de evaluación de resultados de la Red Enlaces, Santiago de Chile: Asesorías para el Desarrollo.

Sánchez, J., \& Salinas, A. (2008). ICT \& learning in Chilean schools: Lessons learned. Computers \& Education, 51(4), 1621-1633.

Selwyn, N. (2010). Schools and schooling in the digital age: A critical analysis. Routledge.

SITEAL (2015). Infraestructura Digital para Educación: Avances y Desafíos para Latinoamérica. Buenos Aires: IIPEUNESCO.

MINEDUC (2017). Informe Nacional: Revisión de las Políticas Educativas en Chile, desde 2004 a 2016, Centro de Estudios, Ministerio de Educación: Santiago.

Pangrazio, L. (2016). Reconceptualising critical digital literacy. Discourse: Studies in the cultural politics of education, 37(2), 163-174

Trucano, M. \& Dykes, G. (2017.) Building and sustaining national educational agencies: Lessons, models and case studies from around the world. Washington, DC: The World Bank. Available at: http://saber.worldbank.org

Severín, E. (2017). Lessons from Chile (Enlaces) in Building and sustaining national educational agencies: Lessons, models and case studies from around the world. Trucano, M. \& Dykes, G. Eds. Washington, DC: The World Bank. Available at: http://saber.worldbank.org 
OECD (2015). Students, Computers and Learning: Making the connection. Paris: OECD.

Subtel (2002). Análisis de Estadísticas por Hogar del Sector Telecomunicaciones Según Censo de Población y Vivienda Chile 2002. http://www.subtel.gob.cl/images/stories/articles/subtel/asocfile/iest_7.pdf

Van Laar, E., van Deursen, A., van Dijk, J., \& de Haan, J. (2017). The relation between 21st-century skills and digital skills: A systematic literature review. [Review]. Computers in Human Behavior, 72, 577-588. doi: 10.1016/j.chb.2017.03.010

Voogt, J., Knezek, G., Christensen, R., Lai, K. W., Pratt, K., Albion, P., .. \& Resta, P. (2017, March). The International Handbook of Information Technology in Primary and Secondary Education: Part 2. In Society for Information Technology \& Teacher Education International Conference (pp. 1082-1085). Association for the Advancement of Computing in Education (AACE).

Williamson, B. (2013). The future of the curriculum: School knowledge in the digital age. MIT Press. 